\title{
AC 2007-2145: INTEGRATING THE TEACHING OF COMPUTER SKILLS WITH AN INTRODUCTION TO MECHANICAL ENGINEERING COURSE
}

\section{Timothy Hinds, Michigan State University}

TIMOTHY J. HINDS is an Academic Specialist in the Michigan State University Department of Mechanical Engineering. He teaches undergraduate courses in machine design, manufacturing processes, mechanics and computational tools. He also teaches a senior-level undergraduate international design project course and has taught graduate-level courses in engineering innovation and technology management. He received his BSME and MSME degrees from Michigan Technological University.

\section{Craig Somerton, Michigan State University}

CRAIG W. SOMERTON is an Associate Professor and Associate Chair of the undergraduate program in the Department of Mechanical Engineering at Michigan State University. He teaches in the area of thermal engineering including thermodynamics, heat transfer, and thermal design. Dr. Somerton has research interests in computer design of thermal systems, transport phenomena in porous media, and application of continuous quality improvement principles to engineering education. He received his B.S. in 1976, his M.S. in 1979, and his Ph.D. in 1982, all in engineering from UCLA. 


\section{Integrating the Teaching of Computer Skills With an Introduction to Mechanical Engineering Course}

\section{Introduction}

Most all engineering programs, mechanical engineering included, have a required computer analysis course that focuses on the development of student programming skills ${ }^{1,2}$. Many mechanical engineering programs also have a course that provides an introduction to the mechanical engineering profession ${ }^{3}$. Both of these courses are typically offered at the freshman level. At Michigan State University (MSU), a retooling of our freshman program has lead to the development of a single course addressing both of these needs. The new course approaches the teaching of these two topics with a problem solving orientation. This paper presents the lessons learned from two pilot runs of this new course entitled: Creative Engineering Solutions. The course is very project oriented with assignments dealing with the disciplines of mechanical engineering, including forces in structures, materials, fluid mechanics, thermal systems, motion and power, manufacturing processes, and mechatronics. Details of the various projects and other student assignments are provided. Course learning objectives that have been developed and set are also shared. Student feedback is presented and the evolution of the course is discussed.

\section{Course Learning Objectives}

A number of course learning objectives were developed by a pilot course task force following a survey of programs at other institutions , $^{4,5}$ and using feedback provided by MSU Department of Mechanical Engineering faculty. Details of the development of the MSU Mechanical Engineering (ME) Freshman Program may be found in previous work by the authors ${ }^{6}$. Learning objectives for the introduction to mechanical engineering with computer skills course were formalized as:

1. Introduce students to the mechanical engineering discipline and profession.

2. Demonstrate how basic mathematics and science fits into engineering practice.

3. Introduce students to the engineering design problem solving method in a rigorous fashion.

4. Teach students to use computer applications such as MATLAB ${ }^{\circledR}$, Excel $^{\circledR}$ and Basic.

5. Help students develop their communication, study, organizational, and teaming skills.

6. Prepare students for and begin their integration into the culture of the mechanical engineering program.

\section{Course Structure}

The three-credit course was taught in a lecture and laboratory format. A syllabus for the course may be found in Appendix 1. Lectures were held twice per week for 50 minutes each. The laboratory sessions also met twice per week for 80 minutes each. To provide students with continuity and a logical connection between the lecture topics and the practice of solution 
methods in the laboratory sessions, lectures and laboratory sessions met on the same days of the week (Tuesdays and Thursdays), with lectures given in a morning class period and the laboratory sessions held in the afternoon. A single instructor taught the course without the aid of teaching assistants in neither the lectures nor the laboratories. Lectures were held in a traditional classroom whereas the laboratory sessions were held in a computer facility populated with Windows ${ }^{\circledR}$-based PCs.

The lectures primarily dealt with the various aspects of the engineering profession and mechanical engineering in particular. Lectures included the topics of innovation, time management, mechanical design methods, engineering problem solving, forces in structures, materials analysis, fluid mechanics, thermal system analysis, mechanical motion analysis, manufacturing processes, and mechatronic system design. An outline of lecture and laboratory session topics, along with a schedule for project presentations and examinations, used for the Fall 2006 semester is given in Appendix 2.

Two lecture examinations were given during the semester. The first, given near the middle of the semester, primarily covered the various aspects of the mechanical engineering subdisciplines and the solving of problems related to those subdisciplines. The second lecture examination, given near the end of the semester, focused on mechatronic system design and analysis.

The laboratory sessions concentrated on application of the lecture topics with utilization of various computer tools. Early in the semester, students learned and practiced technical report writing and presentation skills using Microsoft ${ }^{\circledR}$ Office ${ }^{\circledR}$ products. This was followed by using advanced applications of Excel $^{\circledR}$ to optimize and solve multivariable problems. Then, the students spent nearly half of the semester utilizing MATLAB ${ }^{\circledR}$ to solve problems representative of the mechanical engineering field's subdisciplines. The laboratory portion of the course concluded with the students using a version of Basic to program mechatronic microcontrollers.

\section{Pilot Program Students}

This program was run on a pilot basis during the Spring and Fall 2006 semesters, which overlapped two academic years. For such a pilot, a small number of students needed to be identified to participate in the program. It was decide to tap into the current Residential Option for Science and Engineering Students (ROSES) operated by the MSU College of Engineering 6 .

For the Spring 2006 semester, 14 students participated in the pilot program. Twenty students were selected for the Fall 2006 semester pilot. It is planned for this course to be offered each semester to all incoming mechanical engineering students starting in Fall semester 2007 with approximately 200 students taking the course during the 2007-2008 academic year.

\section{Project Assignments}

The course contained three projects to be completed by the pilot students ${ }^{7,8}$. The first two were performed in 2- or 3-person teams. The final project was performed individually. The following are detailed descriptions and goals of the projects: 


\section{Project 1 Assignment}

The first project followed several lectures and laboratory sessions on technical writing and presentation skills ${ }^{9}$ as well as advanced usage of Excel ${ }^{\circledR}$ spreadsheets for engineering problem solving. The project challenged the students to conceive a feature that would enhance the MSU/East Lansing area. The students formed themselves into teams of 2 or 3 people each. The teams developed conceptual design and were instructed to perform as much design work as was reasonably possible given their limited engineering abilities. The groups made order of magnitude calculations for their designs, used Excel $^{\circledR}$ to perform related engineering calculations and submitted written, technical reports. The teams also made 8-minute presentations to the entire class where each team member was required to present an equal portion of their work.

The primary goal of this project was to expose the students to engineering teamwork and also give them an opportunity to practice their technical writing and presentation skills. The teams were evaluated on their concept design, its feasibility, and a project cost estimation. They were also scored on the detail, quality and delivery of their presentation and written report.

Projects performed by students included a dormitory-housed video rental facility, an underground pedestrian pathway for a congested campus intersection, moving walkways for traversing campus, keyless dormitory doors locks with fingerprint recognition, a campus-wide water filtration system, a dormitory mail distribution system utilizing pneumatic capsules, and protective awnings for bicycle storage. An example of a design developed by a student team may be seen in Figure 1. It is a conceptual design for an underground pedestrian walkway.

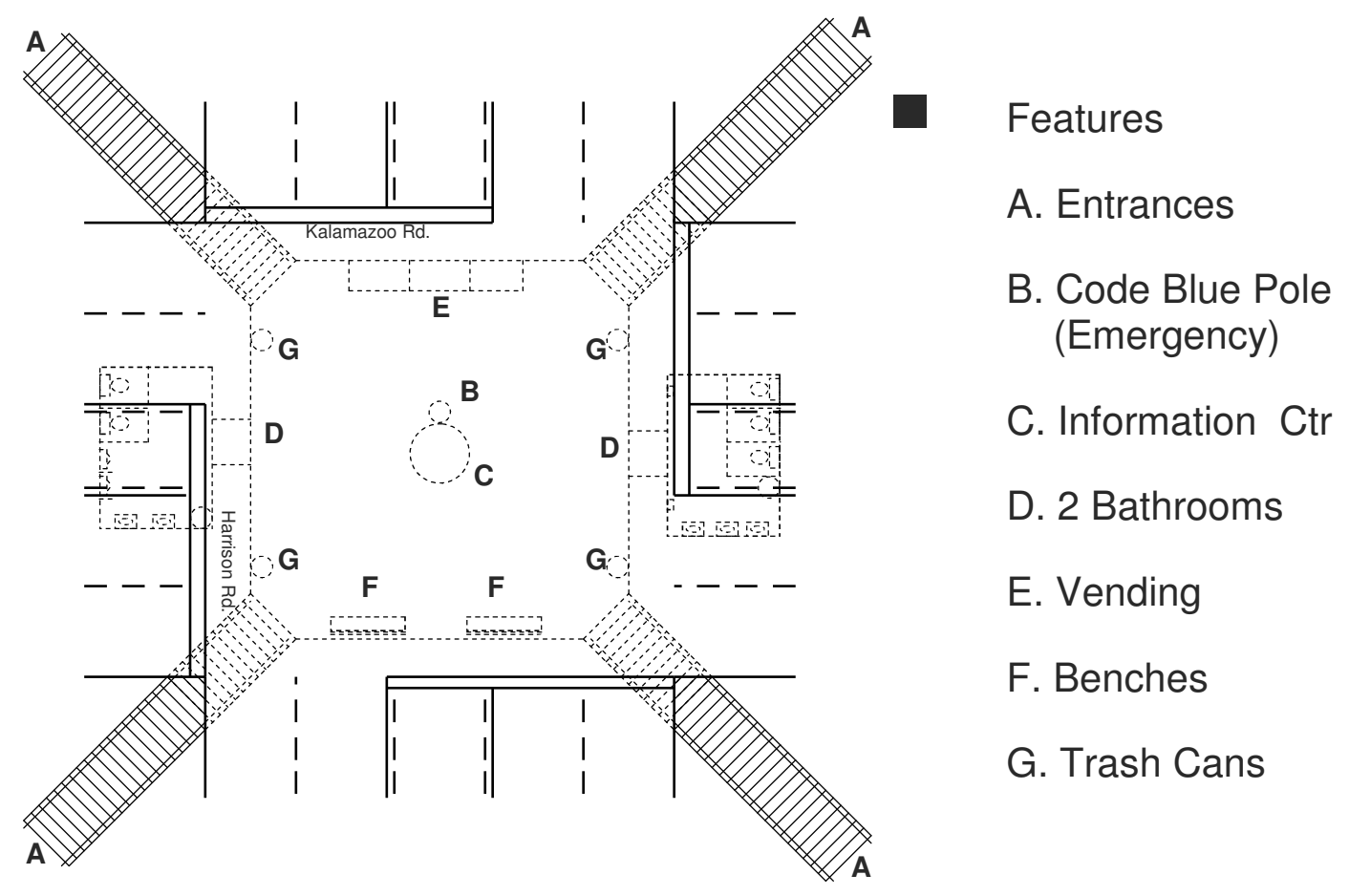

Figure 1: Student Conceptual Design for Underground Intersection Walkway 


\section{Project 2 Assignment}

The second project had the students examine the specifications of the Simon Power Plant which burns several hundred tons of coal per day to produce electricity, heating and cooling, and domestic hot water for the building on the MSU campus. The students were to determine additional usages for hot water prior to its return to the power plant. They again formed themselves into teams of 2 or 3 students, wrote technical reports containing simple engineering calculations on their designs, and presented their work within an 8-minute limit to the class.

Similar to the first project, this assignment again exposed the students to engineering teamwork, technical writing, and presentation. However, the primary goal was to have the students utilize the mechanical engineering problem solving concepts they had learned in the lecture portion of the course along with Excel $^{\circledR}$ and MATLAB ${ }^{\circledR}$ to perform related engineering calculations. The teams were again evaluated on their concept design, its feasibility, and cost, as well as the detail, quality and delivery of their presentation and written report.

Concepts developed by the student teams included heated campus bus stops, high pressure equipment washers, dormitory spa facilities, and additional small-scale power generation. An example of one of the designs, heated campus bus stops, may be seen in Figure 2 below.

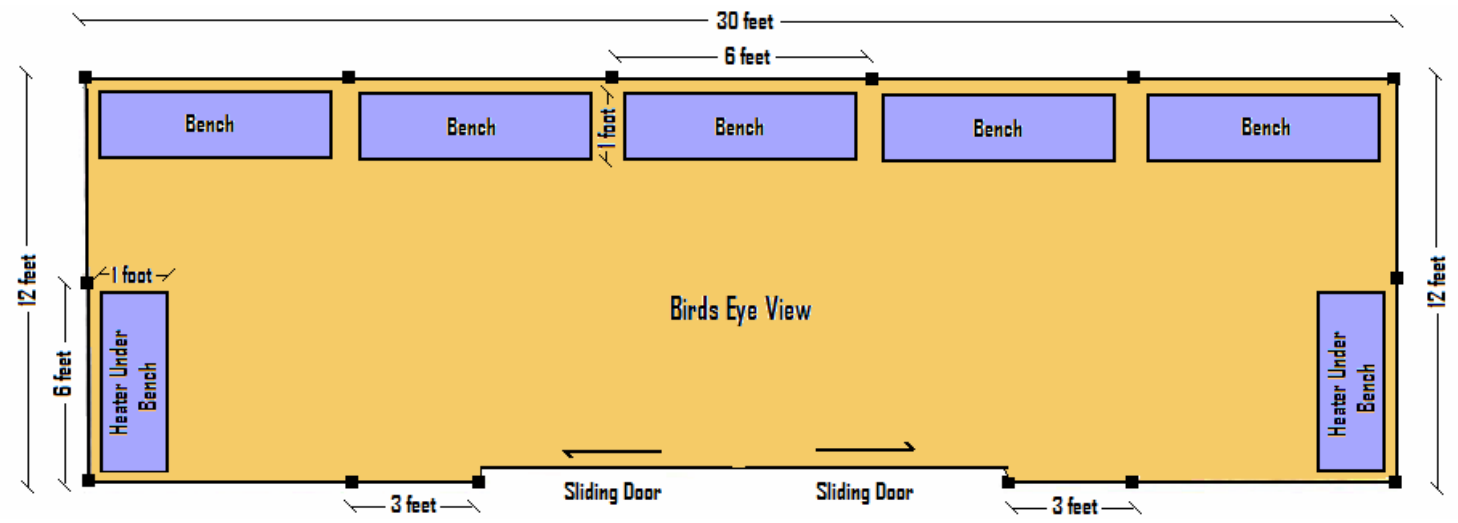

Figure 2: Student Conceptual Design for Heated Bus Stop

\section{Project 3 Assignment}

The final project followed several lecture and laboratory sessions on mechatronics. The students used small prototype boards from Parallax Corp. to learn how to program microprocessors using a form of Basic to operate light emitting diodes, speakers, servo motors, and digital displays. The project had individual students each identify a simple need that could be modeled using the mechatronic systems. The students developed their designs and planned for its construction using standard engineering methodologies to iterate on the identification of a need, definition of the particular problem, synthesis of a solution, analysis and optimization of the solution, and evaluation of the results. They were given a single laboratory session to construct their devices, test and troubleshoot their designs, and verify their subsystem integration. Each student 
presented their work in a 3-minute presentation which included a demonstration of their prototype.

The primary goal of this project was to have the students incorporate the concepts they had learned in lecture and practiced in the laboratory sessions into a unique design. The students were graded on the generation of a proper problem definition, their consideration of design alternatives, their functional prototype, a calculation for expected battery life, and the quality of the presentation.

Mechatronic systems prototyped by individual students included an alarm clock with a night light, a human physical reaction timer, a controller for a dormitory loft ladder, a parking meter timer, a toy car race starter, an automated parking lot gate, a guitar tuner, a violin tuner, a traffic light controller, an automatic night light, a dormitory room heat vent controller, and a motorcycle race starting gate. One such project, a toy car race starter, may be seen in Figure 3 below.

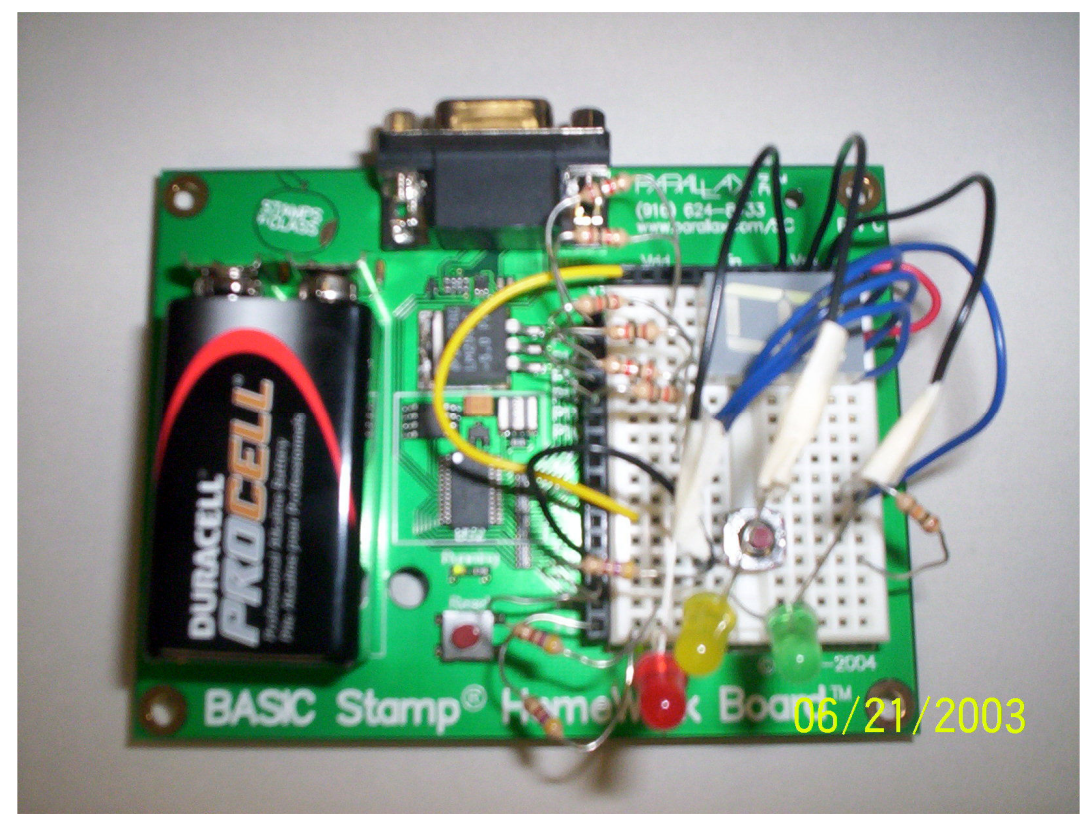

Figure 3: Student Toy Race Car Starter Mechatronic Prototype

\section{Student Feedback}

At the conclusion of the Spring 2006 semester, students were asked to provide feedback on the pilot program so that their comments could be used to improve the course for the second pilot. Among the improvements made were a reduction in the number of projects from four to three, expansion of the mechatronic unit to include digital displays, and the addition of innovation and time management lectures.

The students in the Fall semester 2006 pilot were also asked to provide feedback in the form of a survey intended to assess their skill improvement, knowledge of the mechanical engineering 
profession, and overall impressions of the three projects. Of the 20 students in the fall pilot, 17 submitted responses.

The survey was comprised of four major sections. The first inquired as to each student's mathematical background. The second survey section assessed the students' Windows ${ }^{\circledR}$, Excel ${ }^{\circledR}$, Word $^{\circledR}$, PowerPoint $^{\circledR}$, MATLAB $^{\circledR}$ and Basic skills prior to taking the course as well as following the course. The next section of the survey was used to assess the students' understanding of the engineering profession and their ability to solve engineering problems. The final section had students rate and comment on the three laboratory projects. The survey form may be found in Appendix 3.

The results of the survey found that students felt they had a slight increase, 2.94 to 3.06 on a 4.0 scale, in their Windows ${ }^{\circledR}$ skills following the course. The students also felt their Word ${ }^{\circledR}$ skills had only marginally improved from 3.18 to 3.29. Likewise, there was a small improvement in the students' perception of their PowerPoint ${ }^{\circledR}$ skills with an increase from 2.76 to 3.29. However, there was a significant increase in their Excel ${ }^{\circledR}$ skills, as evidenced by a change from 1.82 to 2.56. Also, the students felt their MATLAB ${ }^{\circledR}$ and Basic abilities had greatly improved from 0.00 to 2.35 and from 0.88 to 2.41 , respectively.

In all cases, a majority of students agreed or strongly agreed that they understood topics covered in the course and could use MATLAB ${ }^{\circledR}$ and Excel ${ }^{\circledR}$ to perform engineering calculations and solve engineering problems. They also agreed that they, by taking this course, had become better problem solvers $(100 \%)$ and technical communicators $(94 \%)$.

With regards to the three projects, 9 of the 17 respondents $(52 \%)$ rated the mechatronic project as the one they enjoyed most. Voting was fairly evenly split among the students as to which project rated second with $6(35 \%)$ each selecting the area improvement and mechatronic projects, and 5 students $(30 \%)$ selecting the power plant steam utilization project. Again, the students rated the area improvement and steam utilization projects nearly evenly, $41 \%$ to $47 \%$, respectively, when evaluating which project rated third.

\section{Conclusions and Recommendations}

As seen in the student feedback, the students clearly enjoyed the mechatronic portion of the course. They were fairly well split on the area improvement and power plant steam utilization projects.

When this course is taught again, the developers, based on student feedback, would discontinue the power plant steam utilization project in favor of a project that utilizes MATLAB ${ }^{\circledR}$ to perform a design optimization.

One of the major challenges still ahead is the scaling up of the program from a small number of hand selected students in a single section to University-wide accessibility to the course by prospective mechanical engineering students, which will lead to expected enrollments of 200 to 300 per semester. 


\section{Acknowledgements}

The authors with to acknowledge the generous support of the DaimlerChrysler Corporation Foundation in providing curriculum development grants for this program in both 2005-2006 and 2006-2007 academic years.

\section{Bibliography}

1 "Cut to the Chase: Extensive Computer Applications in a First Engineering Course," 2005 ASEE Annual Conference \& Exposition, T. Utschig

2 "Freshman Engineering \& Computer Science Program at Wright State University," 2005 ASEE Annual Conference \& Exposition, B. Rowley and T. Bazzoli

3 "An Innovative Approach to the Introduction to Mechanical and Aerospece Engineering Course: Pressure," 2005 ASEE Annual Conference \& Exposition, C. Mavriplis

4 "Designing a Freshman Program to Support Student Success," 2005 ASEE Annual Conference \& Exposition, R. Hensel, J. Byrd and W. Myers

5 "New Paradigm for Foundational Engineering Education," 2005 ASEE Annual Conference \& Exposition, J. Lo, R. Goff, V. Lohani, T. Walker, T. Knott and O. Griffin

6 "The Development of a Mechanical Engineering Freshman Program," 2006 ASEE Annual Conference \& Exposition, T. Hinds, C. Somerton, R. Chalou, C. Radcliffe and G. Griffore

7 "Project Based Learning Design Projects for Introduction to Engineering Design Courses," 2005 ASEE Annual Conference \& Exposition, T. Bayles

8 "Problem Solving and Creativity Experiences for Freshman Engineers," 2005 ASEE Annual Conference \& Exposition, K. High, C. Mann and B. Lawrence

9 "Introducing Presentation Skills in Freshman Engineering," 2005 ASEE Annual Conference \& Exposition, E. Linsky and G. Georgi 
Appendix 1 - Course Syllabus

\section{ME 399 Creative Engineering Solutions I Introduction to Mechanical Engineering}

Fall 2006

$\begin{array}{ll}\text { Instructor: } & \text { Timothy J. Hinds } \\ \text { E-mail address: } & \text { hinds@msu.edu } \\ \text { Office: } & \text { 2453 Engineering Building } \\ \text { Office Phone: } & 432-4139 \\ \text { Lecture: } & \text { Tuesdays \& Thursdays, 9:10-10:00am, 1255ANH } \\ \text { Lab: } & \text { Tuesdays \& Thursdays, 1:00-2:20pm, 1237EB } \\ \text { Office Hours: } & \text { Mondays \& Wednesdays 1:30-3:00pm } \\ \text { Class Web Site: } & \text { www.angel.msu.edu }\end{array}$

Homework: Usually assigned in lab and due the following lab session. No late work will be accepted without prior approval. Re-grades must be requested within 1 week of return of homework, project or exam.

Teaching Assistant: Please see course web site for TA name, office, email and hours.

Text: No text is required. However, the following will be used for reference:

J. Wickert, An Introduction to Mechanical Engineering, Second Edition, 2006.

J. Sticklen \& M. Eskil, An Introduction to Technical Problem Solving with MATLAB v.7, Great Lakes Press, 2005.

\section{Topics Covered:}

ME Curriculum \& Discipline

Mechanical Design

Report Writing \& Presentations

Forces in Structures

Materials

Fluids

Thermal Systems

Due dates: Lab Homework

Lab Project 1

Lecture Exam 1

Lab Project 2

Lecture Exam 2

Lab Project 3
Motion \& Power

Innovation

Manufacturing Processes

Mechatronics

Engineering Problem Solving

Advanced Excel Applications

MATLAB Programming

25\% As Assigned

15\% Thursday, September 21

15\% Thursday, October 19

$15 \%$ Thursday, November 2

15\% Tuesday, December 5

$15 \%$ Thursday, December 7

Grading: $\quad \geq 90.0 \%=4.0,85.0-89.9 \%=3.5,80.0-84.9 \%=3.0,75.0-79.9 \%=2.5$, $70.0-74.9 \%=2.0,65.0-69.9 \%=1.5,60.0-64.9 \%=1.0,<60.0 \%=0.00$ 
Appendix 2 - ME 399 Creative Engineering Solutions I Lecture \& Lab Schedule

\begin{tabular}{|c|c|c|c|c|c|}
\hline Week & Date & $\begin{array}{c}\text { Tuesday } \\
\text { Lecture } \\
\text { Topic }\end{array}$ & $\begin{array}{c}\text { Tuesday } \\
\text { Lab } \\
\text { Topic }\end{array}$ & $\begin{array}{c}\text { Thursday } \\
\text { Lecture } \\
\text { Topic }\end{array}$ & $\begin{array}{c}\text { Thursday } \\
\text { Lab } \\
\text { Topic }\end{array}$ \\
\hline 1 & $8 / 29$ & Introduction & $\begin{array}{c}\text { ME Curriculum } \\
\text { HW \#1 }\end{array}$ & $\begin{array}{l}\text { Mechanical } \\
\text { Design }\end{array}$ & $\begin{array}{c}\text { ME Discipline } \\
\text { HW \#2 }\end{array}$ \\
\hline 2 & $9 / 5$ & $\begin{array}{l}\text { Problem } \\
\text { Solving I }\end{array}$ & $\begin{array}{c}\text { Report Writing } \\
\text { \& Presentations } \\
\text { HW \#3 }\end{array}$ & $\begin{array}{l}\text { Problem } \\
\text { Solving II }\end{array}$ & $\begin{array}{l}\text { Technical } \\
\text { Writing } \\
\text { HW \#4 }\end{array}$ \\
\hline 3 & $9 / 12$ & $\begin{array}{l}\text { Forces in } \\
\text { Structures I }\end{array}$ & $\begin{array}{l}\text { Excel I } \\
H W \# 5\end{array}$ & $\begin{array}{c}\text { Forces in } \\
\text { Structures II }\end{array}$ & $\begin{array}{l}\text { Excel II } \\
\text { HW \#6 }\end{array}$ \\
\hline 4 & $9 / 19$ & Materials I & $\begin{array}{l}\text { Work on } \\
\text { Project } 1\end{array}$ & Materials II & $\begin{array}{c}\text { Project } 1 \\
\text { Presentations }\end{array}$ \\
\hline 5 & $9 / 26$ & Fluids I & $\begin{array}{l}\text { MATLAB Intro } \\
\text { HW \#7 }\end{array}$ & Fluids II & $\begin{array}{c}\text { MATLAB Basics } \\
\text { HW \#8 }\end{array}$ \\
\hline 6 & $10 / 3$ & $\begin{array}{l}\text { Thermal } \\
\text { Systems I }\end{array}$ & $\begin{array}{c}\text { MATLAB Work } \\
\text { HW \#9 }\end{array}$ & No Class & No Class \\
\hline 7 & $10 / 10$ & $\begin{array}{l}\text { Thermal } \\
\text { Systems II }\end{array}$ & $\begin{array}{c}\text { MATLAB Vector } \\
\text { HW \#10 }\end{array}$ & Motion I & $\begin{array}{c}\text { MATLAB Vector } \\
\text { HW \#11 }\end{array}$ \\
\hline 8 & $10 / 17$ & Motion II & $\begin{array}{c}\text { MATLAB Plot } \\
\text { HW \#12 }\end{array}$ & $\begin{array}{l}\text { Lecture Exam } \\
\# 1\end{array}$ & $\begin{array}{c}\text { MATLAB Arrays } \\
\text { HW \#13 }\end{array}$ \\
\hline 9 & $10 / 24$ & Innovation I & $\begin{array}{c}\text { MATLAB Prog } \\
H W \# 14\end{array}$ & Innovation II & $\begin{array}{c}\text { MATLAB 3D } \\
\text { HW \#15 }\end{array}$ \\
\hline 10 & $10 / 31$ & $\begin{array}{c}\text { Time } \\
\text { Management }\end{array}$ & $\begin{array}{c}\text { Work on } \\
\text { Project \#2 }\end{array}$ & $\begin{array}{c}\text { Manufacturing } \\
\text { Processes }\end{array}$ & $\begin{array}{c}\text { Project } 3 \\
\text { Presentations }\end{array}$ \\
\hline 11 & $11 / 7$ & $\begin{array}{l}\text { Mechatronics } \\
\text { Intro }\end{array}$ & $\begin{array}{c}\text { Mec Lab } 1 \\
\text { HW \#16 }\end{array}$ & $\begin{array}{l}\text { Sensors \& } \\
\text { Servos }\end{array}$ & $\begin{array}{c}\text { Sens \& Servos } \\
H W \# 17\end{array}$ \\
\hline 12 & $11 / 14$ & $\begin{array}{l}\text { Sound \& } \\
\text { Memory }\end{array}$ & $\begin{array}{c}\text { Sound \& Mem } \\
\text { HW \#18 }\end{array}$ & Displays & $\begin{array}{l}\text { Displays } \\
\text { HW \#19 }\end{array}$ \\
\hline 13 & $11 / 21$ & $\begin{array}{l}\text { Mechatronic } \\
\text { Integration }\end{array}$ & $\begin{array}{c}\text { Integration } \\
H W \# 20\end{array}$ & No Class & No Class \\
\hline 14 & $11 / 28$ & Project 3 Intro & $\begin{array}{l}\text { Project } 3 \\
H W \# 21\end{array}$ & $\begin{array}{c}\text { Project } 3 \\
\text { Presentation }\end{array}$ & $\begin{array}{c}\text { Project } 3 \text { Pres } \\
\text { HW \#22 }\end{array}$ \\
\hline 15 & $12 / 5$ & $\begin{array}{c}\text { Lecture Exam } \\
\text { \#2 }\end{array}$ & $\begin{array}{l}\text { Work on } \\
\text { Project \#3 }\end{array}$ & $\begin{array}{c}\text { Course Wrap } \\
\text { Up }\end{array}$ & $\begin{array}{c}\text { Project } 3 \\
\text { Presentations }\end{array}$ \\
\hline
\end{tabular}




\section{Appendix 3 - Student Opinion Post Survey}

\section{Mechanical Engineering Freshman Program Student Opinion Post Survey - Fall 2006}

1. The highest level of math I took in high school was:

2. The math I took fall semester 2006 was:

3. The math I plan to take spring semester 2007 is:

For questions 4-15, please reply with: None, Minimal, Average, Good or Very Good

4. Before I took ME399, I would rate my Windows skills as:

5. Since completing ME399, I would rate my Windows skills as:

6. Before I took ME399, I would rate my Excel skills as:

7. $\quad$ Since completing ME399, I would rate my Excel skills as:

8. Before I took ME399, I would rate my Word skills as:

9. $\quad$ Since completing ME399, I would rate my Word skills as:

10. Before I took ME399, I would rate my PowerPoint skills as:

11. Since completing ME399, I would rate my PowerPoint skills as:

12. Before I took ME399, I would rate my MATLAB skills as:

13. Since completing ME399, I would rate my MATLAB skills as:

14. Before I took ME399, I would rate my Basic skills as:

15. Since completing ME399, I would rate my Basic skills as:

For questions 16-26, respond with: Strongly Agree, Agree, Disagree or Strongly Disagree

16. I can perform mathematical calculations using MATLAB

17. I can solve simple engineering problems using MATLAB

18. I can solve complex engineering problems using MATLAB

19. I can perform mathematical calculations using Excel

20. I can solve simple engineering problems using Excel

21. I can solve complex engineering problems using Excel

22. I understand the mechanical engineering profession

23. I understand what a practicing mechanical engineer does

24. ME399 has helped me to better understand the ME curriculum at MSU

25. ME399 has helped me to become a better technical problem solver

26. ME399 has helped me become a better technical communicator

Questions 27-32 deal with the 3 projects performed in ME399. They were:

Project 1 - MSU/East Lansing Community Improvement Design

Project 2 - Simon Power Plant Steam Usage Design

Project 3 - Mechatronics Design

27. The best ME399 project in terms of learning was:

28. Why is this project rated first?

29. The second best ME399 project in terms of learning was:

30. Why is this project rated second?

31. The third best ME399 project in terms of learning was:

32. Why is this project rated third?

33. Any other comments you wish to share? 